\title{
Vitamin C partially prevents reproductive damage in adult male rats exposed to rosuvastatin during prepuberty
}

\author{
Gabriel Adan Araújo Leite a, b, *, Thamiris Moreira Figueiredo b, Tainá Louise Pacheco b, \\ Marciana Sanabria ${ }^{\mathrm{b}}$, Patrícia Villela e Silva ${ }^{\mathrm{b}}$, Fábio Henrique Fernandes ${ }^{\mathrm{c}}$, \\ Wilma De Grava Kempinas ${ }^{\text {b }}$
}

${ }^{a}$ Graduate Program in Cell and Structural Biology, Institute of Biology, State University of Campinas - UNICAMP, Campinas, Brazil

${ }^{\mathrm{b}}$ Department of Morphology, São Paulo State University (Unesp), Institute of Biosciences, Botucatu, Brazil

${ }^{c}$ Graduate Program in Genetics, São Paulo State University (Unesp), Institute of Biosciences, Botucatu, Brazil

\section{A R T I C L E I N F O}

\section{Article history:}

Received 16 January 2017

Received in revised form

19 August 2017

Accepted 2 September 2017

Available online 6 September 2017

\section{Keywords:}

Ascorbic acid

Rosuvastatin

Male reproduction

Toxicology

\begin{abstract}
A B S T R A C T
Pediatric obesity is closely associated with dyslipidemias and environmental factors, such as diet and lack of physical exercises, which may alter lipid profile in children. Rosuvastatin decreases serum total cholesterol and triglycerides concentrations. Vitamin C (ascorbic acid) plays an important role on sperm integrity and fertility. Juvenile male rats were distributed into six experimental groups that received saline solution $0.9 \%, 3$ or $10 \mathrm{mg} / \mathrm{kg} /$ day of rosuvastatin, $150 \mathrm{mg} /$ day of ascorbic acid, or 3 or $10 \mathrm{mg} / \mathrm{kg} / \mathrm{day}$ of rosuvastatin co-administered with $150 \mathrm{mg} /$ day of ascorbic acid from PND23 until PND53 and then the rats were maintained until sexual maturity. Rosuvastatin-exposed groups showed lower sperm quality, androgen depletion and germ cell death. Ascorbic acid was capable to prevent partially the reproductive adverse effects provoked by rosuvastatin. In conclusion, prepubertal exposure to rosuvastatin provokes long-term reproductive damages at sexual maturity and ascorbic acid supplementation at prepuberty may be a preventive mode against these reproductive adverse effects.
\end{abstract}

(๑) 2017 Elsevier Ltd. All rights reserved.

\section{Introduction}

Obesity, one of the greatest emerging problems of public health, has been affecting adults, children and adolescents (Jiménez and Ferre, 2011). Moreover, obesity is not only a common metabolic and nutritional disorder in developed countries but is also affecting underdeveloped countries (Jiménez and Ferre, 2011).

Pediatric obesity is closely related to dyslipidemias and has been associated with increased risk of cardiovascular diseases, insulin resistance, hypertension, accelerated atherosclerosis (Klop et al., 2013; McGill et al., 2002), metabolic syndrome, reproductive and sleepiness disorders and psychological alterations (Seth and Sharma, 2013).

Genetic factors are the main cause of pediatric dyslipidemias; however, environmental factors such as diet and a lack of physical

\footnotetext{
* Corresponding author. Rua Prof. Dr. Antonio Celso Wagner Zanin, s/n, Departamento de Morfologia, Instituto de Biociências, UNESP, 18618-689, Botucatu, SP, Brazil.

E-mail address: gabriel_adan_1990@hotmail.com (G.A.A. Leite).
}

exercise may contribute to inducing changes in the lipid profile (Ross, 2016). Statins are first-line therapy medications recommended for children with dyslipidemia in order to improve their lipid profile by diminishing LDL-cholesterol, VLDL-cholesterol and triglycerides, as well as increasing HDL-cholesterol, when such lifestyle changes as adherence to an appropriate diet and regular practice of physical exercise are not sufficient to diminish serum total cholesterol (Jiménez and Ferre, 2011; Ross, 2016).

Statins are inhibitors of the enzyme 3-hydroxy-methylglutaryl coenzyme A (HMG-CoA) reductase, which is a limiting enzyme to the biosynthesis of the cholesterol molecule (Istvan and Deisenhofer, 2001; Jiménez and Ferre, 2011); thus, statins are capable of diminishing total cholesterol, decreasing mainly LDLcholesterol (Istvan and Deisenhofer, 2001; Tandon et al., 2005; Endres, 2006).

These drugs play relevant roles in the organism through their pleiotropic effects that are related to the diminution of intermediate isoprenoids such as geranylgeranyl pyrophosphate (GGPP) and farnesyl pyrophosphate (FPP) (Adam and Laufs, 2008). The main pleiotropic effects include atherosclerosis stabilization, improvement on endothelial function and higher nitric oxide 
bioavailability, by which they act to prevent cardiovascular diseases (Ludman et al., 2009; Tandon et al., 2005).

Rosuvastatin has pharmacological advantages in relation to the other statins and presents unique characteristic binding with the enzyme HMG-CoA reductase, as well as superior inhibitory effects when compared to the other statins, thus leading to higher decreased levels of total cholesterol (Holdgate et al., 2003; McTaggart, 2003).

Children and adolescents are often exposed to chemical compounds that may modify not only puberty timing but also the acquisition and development of reproductive capability (Stoker et al., 2000). Several studies have reported that reproductive disorders during puberty may affect reproduction in adulthood (Perobelli et al., 2012, 2013; Mantovani and Fucic, 2014).

Recent studies have attempted to reverse or diminish the adverse effects provoked by various pathologies, metabolic dysfunctions or even chemical compounds used as relevant medications in several treatments (Fernandes et al., 2011a, 2011b; Mukhopadhyay et al., 2013).

The co-administration of substances that have an antioxidant potential or another mode of action that may prevent or reverse the adverse effects of a chemical compound has been widely studied (Corsetti et al., 2011; Mukhopadhyay et al., 2013; Pandir et al., 2014; Sooriyaarachchi et al., 2012), because many medications are needed for the treatment of metabolic dysfunctions and other diseases (Pandir et al., 2014; Sooriyaarachchi et al., 2012).

Vitamin C, also denominated ascorbic acid, is a water-soluble molecule and an important vitamin for the functioning of the organism (Sönmez et al., 2005), and is essential for norepinephrine and collagen biosynthesis, besides contributing to $\alpha$-tocopherol recycling (Fernandes et al., 2011a, 2011b). Furthermore, ascorbic acid is an antioxidant compound that is not synthetized by humans; therefore, it is necessary to acquire the vitamin from the diet (Fernandes et al., 2011a).

Ascorbic acid plays a significant role in sperm integrity and fertility, acting as a protective compound for spermatogenesis and as an antioxidant substance against oxidative stress (Agarwal et al., 2005; Eskenazi et al., 2005; Shrilatha and Muralidhara, 2007; Fernandes et al., 2011b). In addition, ascorbic acid may increase testosterone concentrations and is found in the epididymal fluid and semen where it prevents excessive lipid peroxidation (Sönmez et al., 2005).

One previous study showed delayed reproductive development in prepubertal male rats exposed to rosuvastatin, accompanied by delayed puberty installation, increased germ cell death in the testis, delayed epididymal development during the postnatal period, androgen depletion (Leite et al., 2017, 2014) and diminished expression of androgen receptors in both the testes and the epididymis (Leite et al., 2014). A previous in vitro study assessing rat Leydig cells treated with statins showed reduced testosterone production when stimulated by LH (Klinefelter et al., 2014). Another study of men observed that rosuvastatin administration decreased testosterone levels, without affecting sexual function (Hsieh and Huang, 2016). In addition, a previous study on another statin, named atorvastatin, showed reduced sperm quality in men treated with the drug during adulthood (Pons-Rejraji et al., 2014). According to these several studies, statins seem able to interfere with male reproduction.

Considering the utilization of lipid-lowering drugs by children and adolescents and the delay in the reproductive development of prepubertal male rats exposed to rosuvastatin, the present study aims to assess the long-term adverse effects of prepubertal exposure to rosuvastatin and whether prepubertal supplementation with ascorbic acid may diminish or prevent the possible reproductive damage in adulthood.

\section{Material and methods}

\subsection{Animals}

\subsubsection{Obtainment of pups and reduction of litters}

Male and female (45 days of age) nonpathogenic free Wistar rats were supplied by the Central Biotherium at the State University of São Paulo (UNESP), Botucatu/SP and maintained in the Small Mammal Biotherium of the Morphology Department at the UNESP Biosciences Institute, Botucatu.

Rats were housed in polypropylene cages $(43 \mathrm{~cm} \times 30 \mathrm{~cm} \times 15 \mathrm{~cm}$ ) with laboratory grade pine shavings as bedding. Animals were maintained under controlled conditions for temperature $\left(23 \pm 1{ }^{\circ} \mathrm{C}\right)$ and lighting (12:12h photoperiod). The health status of the rats was monitored throughout the experiment. Standard rodent chow (Purina Labina, Agribrands do Brasil Ltda, Paulínia/SP, Brazil) and filtered tap water were provided ad libitum.

During sexual maturity two nulliparous female rats ( 75 days of age) were mated with one male (90 days of age) during the dark phase of the lighting cycle; the day of sperm detection in the vaginal smear of female rats in estrus was considered gestational day 0 (GD 0). Pregnant and lactating female rats were maintained in individual cages.

After birth, the number of pups per litter was reduced to eight on postnatal day (PND) 4 to balance male and female pups ( 4 each per litter). Litters with fewer than eight pups were not included in the experimental protocol and were euthanized.

\subsubsection{Experimental design}

On PND 23, male pups were distributed into six experimental groups ( $n=10$ per group, with one pup per litter for each group), that received vehicle (saline solution $0.9 \%$, control group), supplementation with $150 \mathrm{mg} /$ day of ascorbic acid (AA), 3 or $10 \mathrm{mg} / \mathrm{kg} /$ day of rosuvastatin diluted in saline solution $0.9 \%$ (3 mg or $10 \mathrm{mg}$ ) or $150 \mathrm{mg} /$ day of ascorbic acid associated with 3 or $10 \mathrm{mg} / \mathrm{kg} /$ day of rosuvastatin ( $3 \mathrm{mg}+\mathrm{AA}$ or $10 \mathrm{mg}+\mathrm{AA}$ ). Ascorbic acid and rosuvastatin were purchased from Farmácia Botica Oficinal (Botucatu/ Brazil). The treatments were administered by gavage from PND 23 until PND 53, following the male pubertal assay of 31 days recommended by the U.S. Environmental Protection Agency (EPA) (Stoker et al., 2000).

The doses of rosuvastatin available to diminish total cholesterol and LDL-cholesterol often used by humans are between 5 and $40 \mathrm{mg} /$ day (Vaughan and Gotto Jr., 2004); thus, the doses used in this study were based on body surface area correction considering the available doses of rosuvastatin for children and their conversion to equivalent doses for juvenile rats (Reagan-Shaw et al., 2008). The doses of ascorbic acid supplementation were based on previous studies (Fernandes et al., 2011a, 2011b). During the treatment, the rats were monitored in relation to indications of distress, such as the presence of bristling hair and the ingestion of food and water. Rats were maintained until sexual maturity, when a sexual behavior test was performed, followed by euthanasia of the rats ten days later.

The experimental protocol followed the Ethical Principles in Animal Research of the Brazilian College of Animal Experimentation and was approved by the Biosciences Institute/UNESP Ethics Committee for Animal Experimentation (protocol number 589CEUA).

Male rats were euthanized on PND 110, after performing the sexual behavior test on PND 100, in order to evaluate the long-term reproductive effects due to rosuvastatin exposure and/or ascorbic acid supplementation at prepuberty. Therefore, the following parameters were obtained: final body weight, reproductive and vital organ weights, testicular and epididymal histopathology, testicular 
morphometry, sperm counts, motility and morphology and hormonal serum concentrations. Moreover, the rats were evaluated in relation to their reproductive performance and fertility after the sexual behavior test.

\subsection{Evaluation of male sexual behavior}

Male rats were placed individually in polycarbonate crystal cages, measuring $44 \times 31 \times 16 \mathrm{~cm}, 5 \mathrm{~min}$ before the introduction of one adult female in natural proestrus or estrus (sexually receptive) determined by vaginal smear. Behavioral testing was conducted in the dark period of the cycle between 8:00 a.m. and 12 p.m. in a separate room under dim red illumination. If the male rat did not mount within the next $10 \mathrm{~min}$, a second try was permitted on the next day.

The following measures were recorded (Ahlenius and Larsson, 1984): mount and intromission latencies, defined as the times from introduction of the female in the cage to the first mount and intromission, respectively; the number of intromissions preceding the first ejaculation; ejaculation latency, the time from introduction of the female in the cage to the first ejaculation; latency to the first post-ejaculatory intromission, the time to the first intromission after the first ejaculation; the number of intromissions after the first ejaculation and total number of ejaculations. During the second chance, if the male did not mount in the first $10 \mathrm{~min}$ following the introduction of one receptive adult female into the box, it was considered sexually inactive.

\subsection{Euthanasia of the rats, body weight and organ weights}

Male rats were weighed on PND 110 and euthanized following narcosis by $\mathrm{CO}_{2}$ asphyxiation and thereafter, blood was collected by inferior vena cava, between 9:00 and 11:30 a.m. Reproductive organs, such as, left testis, epididymis and vas deferens, seminal gland (full and empty, without the coagulating gland) and ventral prostate, from the rats were collected and weighed. Vital organs that perform an important role in toxicological parameters, such as kidneys, adrenal glands, liver, thyroid, pituitary and brain were also obtained and weighed.

\subsection{Serum hormonal concentrations}

Serum was obtained by centrifugation ( $2400 \mathrm{rpm}, 20 \mathrm{~min}, 4^{\circ} \mathrm{C}$ ) in a refrigerated device and was frozen at $-20^{\circ} \mathrm{C}$ until the moment of hormonal determination. Testosterone, FSH and LH were determined by the double-antibody radioimmunoassay. LH and FSH used specified kits supplied by the National Institute of Arthritis, Diabetes and Kidney Diseases (NIADDK) and testosterone concentrations were measured by the kit Testosterone Maia (Biochem Immuno System, Allentown, PA, USA). All samples were measured in the same assay to avoid the inter-assay errors. Intra-assay variabilities were $3.4 \%$ for $\mathrm{LH}, 2.8 \%$ for $\mathrm{FSH}$, and $4 \%$ for testosterone.

\subsection{Sperm motility}

Sperm motility was evaluated immediately after euthanasia. The right epididymal cauda was collected, sperm were obtained and a sample was diluted in $2 \mathrm{~mL}$ of the modified HTF medium (Spectrun $90,126)$, then a $10 \mu \mathrm{L}$ aliquot was transferred to a Mackler chamber. Under a light microscope $(20 \times$ magnification), 100 spermatozoa were analyzed and classified as: type A, motile with regular and fast progressive movement; type $\mathrm{B}$, motile with non-progressive movement or type $C$, immotile. Sperm motility was expressed as the percentage of total sperm (Perobelli et al., 2012).

\subsection{Sperm morphology}

Sperm were extracted from the right epididymal cauda of all rats, diluted in modified HTF medium and a sample was obtained and added to $1.0 \mathrm{~mL}$ of saline formol. For the analysis, smears were prepared on histological slides that were left to dry for $90 \mathrm{~min}$ and observed in a phase-contrast microscope (400× magnification); 200 spermatozoa were analyzed per animal (Seed et al., 1996). Morphological abnormalities were classified into general categories pertaining to head morphology (without curvature, without characteristic curvature, pin head or isolated form, i.e., no tail attached) and tail morphology (broken, isolated, i.e., no head attached, or rolled into a spiral). In addition, the presence and position (proximal, medial or distal) of the cytoplasmic droplet were evaluated in the same sperm (Filler, 1993).

\subsection{Sperm counts in the testis and epididymis, and sperm transit time}

Homogenization-resistant testicular spermatids (stage 19 of spermiogenesis) were enumerated as described previously (Robb et al., 1978), with the following adaptations: the right testis, decapsulated and weighed soon after collection, was homogenized in $5 \mathrm{~mL}$ of $\mathrm{NaCl} 0.9 \%$ containing Triton X $1000.5 \%$, followed by sonication for $30 \mathrm{~s}$. After a 10 -fold dilution a sample was transferred to Neubauer chambers ( 4 fields per animal), where mature spermatids were enumerated. To calculate the daily sperm production (DSP), the number of spermatids at stage 19 was divided by 6.1, which is the number of days of the seminiferous cycle in which these spermatids are present in the seminiferous epithelium.

To obtain the number of mature spermatids per gram of testis and the relative DSP, the number of mature spermatids and the DSP were divided by the weight of the testicular parenchyma. In the same manner, caput/corpus and cauda epididymis parts were cut into small fragments with scissors and homogenized, and sperm enumerated as described for the testis. The sperm transit time through the epididymis was determined by dividing the number of sperm in each part of the organ by the DSP.

\subsection{Sperm DNA fragmentation (comet assay)}

The comet assay was used for detecting primary DNA damage (single- and double-strand breaks and alkali-labile sites) in sperm isolated from the cauda epididymis that were maintained in HTF medium stored at $-80{ }^{\circ} \mathrm{C}$. The alkaline version of the assay was performed according to a previous study (Tice et al., 2000). Briefly, $5 \mu \mathrm{L}$ of the HTF medium with sperm sample was mixed with $75 \mu \mathrm{L}$ of low-melting-point agarose (0.5\%) and then placed onto slides that had previously been covered with a thin layer of normalmelting-point agarose (1.5\%). The slides were covered with lysis solution (100 mM Na2-EDTA, $10 \mathrm{mM}$ TrisHCl, 2.5M NaCl, pH 11, containing $40 \mathrm{mM}$ DTT and $2 \%$ Triton X-100) and incubated for $1 \mathrm{~h}$ at $4{ }^{\circ} \mathrm{C}$. Next, the slides were submitted to a second lysis solution containing proteinase $\mathrm{K}(100 \mu \mathrm{g} / \mathrm{mL})$ for $2 \mathrm{~h}$ and $30 \mathrm{~min}$ at $37^{\circ} \mathrm{C}$ and were subsequently incubated in a horizontal electrophoresis tank containing freshly prepared cold alkaline electrophoresis buffer (300 mM NaOH, $1 \mathrm{mM} \mathrm{Na} 2$ EDTA, pH > 13) for 45 min to allow the DNA to unwind and for alkali-labile site expression in a cold room. Electrophoresis was conducted in the same alkaline buffer for $20 \mathrm{~min}$ at $3 \mathrm{~V} / \mathrm{cm}$ and $270 \mathrm{~mA}$ at $4{ }^{\circ} \mathrm{C}$. Then, the slides were washed in PBS solution, rinsed in water, fixed in absolute ethanol and stored at room temperature until analysis. The slides were stained with SYBR $^{\circledR}$ Gold (1:10,000; Invitrogen; Grand Island, NY, USA) immediately before analysis. A total of 100 randomly selected nucleoids per animal was analyzed under $400 \times$ magnification with a 
fluorescence microscope connected to an image analysis system (Comet Assay IV, Perceptive Instruments; Suffolk, Haverhill, UK). Tail intensity (\% DNA in tail) was used to estimate DNA damage. The slides were prepared in duplicate and all steps were conducted in the dark to prevent additional DNA damage.

\subsection{Histological procedures}

The left testis and epididymis were collected and fixed in Bouin's fluid, embedded in Paraplast ${ }^{\circledR}$ and sectioned in $4 \mu \mathrm{m}$ cuts (transversal sections of testis and longitudinal sections of epididymis). Sections were stained with hematoxylin and eosin (HE) to evaluate testicular and epididymal morphology under light microscopy. The evaluation was performed in a blind assay and the figures were obtained using a Leica light microscope coupled to a digital camera and a personal computer with the software Leica Qwin version 3 for Windows.

Seminiferous tubule cross-sections were randomly chosen in three non-serial testicular sections per animal obtained with a distance of $50 \mu \mathrm{m}$ among them, totaling 200 tubules evaluated per animal. Seminiferous tubules were classified as: normal (presence of concentric and normally organized germ cell layers in seminiferous epithelium) or abnormal (presence of germ cells and cellular debris in the lumen, multinucleated formation, seminiferous epithelium with acidophilic cells, few germ cell layers, vacuole formation or degeneration in seminiferous epithelium).

Histopathological analysis of interstitial tissue and peritubular myoid cells was qualitative; the interstitial analysis aimed to assess Leydig cell morphology and the appearance of blood vessels. Epididymal histopathological analysis was also qualitative to evaluate each region of the organ according to the epithelium, lumen and interstitial tissue morphological appearance.

\subsection{Testicular morphometric analysis}

Tubular and luminal area of the seminiferous tubules and epithelial height of the seminiferous epithelium were measured using a Leica light microscope coupled to a digital camera and a personal computer with the software Leica Qwin Version 3 for Windows. For this, 30 random seminiferous tubules from testicular cross-sections (stage IX of the seminiferous epithelium cycle) per animal ( $\mathrm{n}=9$ or 10 animals/group) were examined blindly at $\times 200$ magnification. To assess spermatogenesis kinetics, one hundred random tubular sections per animal ( $\mathrm{n}=9$ or 10 animals/group) in three non-consecutive testis cross-sections were classified into four categories: stages I-VI, VII-VIII, IX-XIII and XIV of the seminiferous epithelium cycle (Leblond and Clermont, 1952), under a light microscope (Zeiss, Axiostar plus, Oberkochen, Germany) at $\times 200$ magnification.

\subsection{Fertility and reproductive performance}

This analysis was carried out following natural mating. In the case of rats that had ejaculated during the evaluation of sexual behavior, couples stayed together for an additional $4 \mathrm{~h}$, allowing a greater number of ejaculations. Animals that had been deemed inactive were tested again daily for the next 5 consecutive days during which different receptive females were placed in their boxes during the dark period of the cycle.

Every morning, males were separated from the females, and vaginal smears of each female were examined for the presence of sperm. The day on which sperm were found in the vaginal smear was considered day 0 of gestation (GD 0). On the 20th day of gestation (GD 20) females were weighed and then euthanized following narcosis by $\mathrm{CO}_{2}$ asphyxiation and decapitation. After collection of the uterus and ovaries, the gravid uterus weight was obtained; corpora lutea, implantation sites, reabsorptions and live fetuses were enumerated and fetal and placental weights were determined.

Based on these results, the following were determined: gestation rate $=$ number of pregnant females/number of inseminated females $x$ 100; fertility potential (efficiency of implantation) $=$ implantation sites/corpora lutea $\mathrm{x} 100$; rate of post-implantation loss $=$ number of implantations - number of live fetuses/number of implantations x 100; sex ratio = number of male fetuses/number of female fetuses $\mathrm{x} 100$.

\subsection{Statistical analysis}

For comparison of the results among the experimental groups, two-way ANOVA was performed, followed by Bonferroni's test. Differences were considered statistically significant when $\mathrm{p} \leq 0.05$. Statistical analyses were performed on GraphPad Prism (version $5.00)$.

\section{Results}

\subsection{Hormonal measurements, sexual behavior and reproductive performance}

Serum testosterone concentrations were decreased during adulthood in the rosuvastatin-exposed groups in a dose-dependent manner, when compared to the control group ( $p<0.05$ ) (Fig. 1). Prepubertal supplementation with ascorbic acid was capable of preventing androgen depletion during sexual maturity (Fig. 1). LH and FSH concentrations were similar among the experimental groups (Fig. 1).

The sexual behavior test did not show significant differences among the experimental groups for assessed parameters that include latency to the first mount, intromission, ejaculation and first post-ejaculatory intromission, as well as the numbers of mounts, intromissions and ejaculations (Table 1).

Reproductive performance and fertility evaluated by natural mating showed an elevated rate of post-implantation loss in the group exposed to the higher dose of rosuvastatin during prepuberty, in comparison with control group ( $p<0.05$ ) (Table 2). Ascorbic acid supplementation partially prevented the increased rate of post-implantation loss in the group co-exposed to $10 \mathrm{mg}$ of rosuvastatin and ascorbic acid (Table 2 ). The remaining parameters evaluated for reproductive performance and fertility showed no significant differences among the groups (Table 2).

\subsection{Sperm parameters}

Daily sperm production and mature spermatids number per testis, relative daily sperm production and mature spermatids number per gram of organ ( $p<0.05$ ) were lower in the rosuvastatin-treated groups when compared to the control group (Table 3). Ascorbic acid supplementation at prepuberty was able to prevent the reduction of testicular sperm counts in the co-exposed groups (Table 3).

Sperm counts in the caput and corpus epididymis were lower in the groups treated with rosuvastatin at prepuberty, in comparison with the control group $(\mathrm{p}<0.05$ ) (Table 3 ). Ascorbic acid partially prevented the diminished sperm counts in the group co-exposed to $10 \mathrm{mg}$ of the statin and ascorbic acid (Table 3). Rosuvastatinexposed rats presented a lower number of sperm per gram of caput and corpus and diminished sperm storage in the cauda ( $p<0.05$ ); however, ascorbic acid supplementation was sufficient to prevent this adverse result (Table 3 ). 

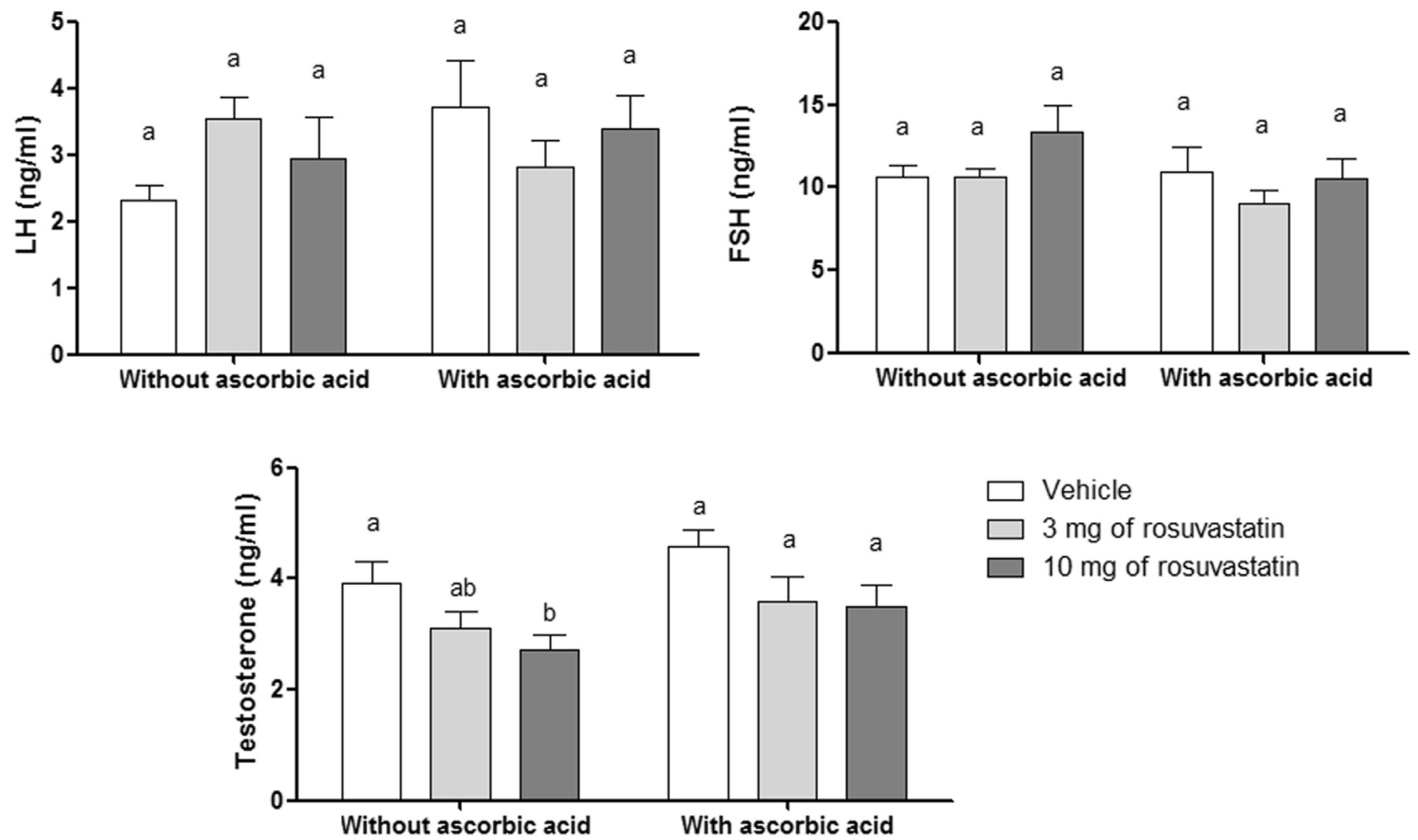

Vehicle

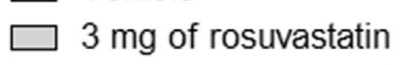

$\square 10 \mathrm{mg}$ of rosuvastatin

Without ascorbic acid

With ascorbic acid

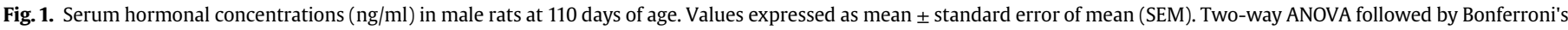
test. $\mathrm{p}<0.05$. Different letters indicate statistically significant differences among the groups.

Table 1

Sexual behavior test from the experimental groups on post-natal day (PND) 100 .

\begin{tabular}{|c|c|c|c|c|c|c|}
\hline & \multicolumn{6}{|c|}{ Experimental Groups $(\mathrm{n}=7)$} \\
\hline & Control & $3 \mathrm{mg}$ & $10 \mathrm{mg}$ & AA & $3 \mathrm{mg}+\mathrm{AA}$ & $10 \mathrm{mg}+\mathrm{AA}$ \\
\hline Latency to the first mount (s) & $188.56 \pm 50.73$ & $115.50 \pm 50.02$ & $198.71 \pm 63.96$ & $133.25 \pm 31.82$ & $188.33 \pm 57.84$ & $151.43 \pm 43.44$ \\
\hline Number of mounts until de first intromission & $4.33 \pm 0.80$ & $4.56 \pm 1.18$ & $8.60 \pm 2.47$ & $7.30 \pm 2.20$ & $4.20 \pm 0.59$ & $9.00 \pm 2.77$ \\
\hline Latency to the first intromission $(\mathrm{s})$ & $245.00 \pm 67.58$ & $175.89 \pm 61.08$ & $207.78 \pm 59.46$ & $147.12 \pm 28.86$ & $188.71 \pm 62.05$ & $208.87 \pm 82.59$ \\
\hline Number of intromissions until the first ejaculation & $15.50 \pm 2.64$ & $17.89 \pm 2.65$ & $19.00 \pm 3.28$ & $23.00 \pm 3.09$ & $22.33 \pm 1.05$ & $24.00 \pm 3.39$ \\
\hline Latency to the first ejaculation (s) & $1093.12 \pm 169.01$ & $1270.83 \pm 194.47$ & $890.86 \pm 189.00$ & $884.87 \pm 161.78$ & $797.20 \pm 134.89$ & $1108.17 \pm 159.68$ \\
\hline Latency to the first post-ejaculatory intromission (s) & $338.62 \pm 21.20$ & $375.50 \pm 26.13$ & $318.00 \pm 11.47$ & $311.71 \pm 16.06$ & $255.33 \pm 8.59$ & $287.83 \pm 10.19$ \\
\hline Number of post-ejaculatory intromission & $9.37 \pm 1.67$ & $11.00 \pm 4.16$ & $9.29 \pm 0.24$ & $11.71 \pm 0.94$ & $11.67 \pm 4.28$ & $9.33 \pm 2.15$ \\
\hline Number of ejaculations & $2.00 \pm 0.33$ & $1.50 \pm 0.34$ & $2.71 \pm 0.42$ & $2.50 \pm 0.42$ & $3.00 \pm 0.36$ & $2.17 \pm 0.30$ \\
\hline
\end{tabular}

Values expressed as mean \pm standard error of mean (SEM), $\mathrm{p}>0.05$. Two-way ANOVA followed by Bonferroni's test.

Table 2

Reproductive performance and fertility test from the experimental groups on PND110.

\begin{tabular}{|c|c|c|c|c|c|c|}
\hline & \multicolumn{6}{|c|}{ Experimental Groups ( $\mathrm{n}=9$ or $10 /$ group) } \\
\hline & Control & $3 \mathrm{mg}$ & $10 \mathrm{mg}$ & $\mathrm{AA}$ & $3 \mathrm{mg}+\mathrm{AA}$ & $10 \mathrm{mg}+\mathrm{AA}$ \\
\hline Gestational rate (\%) & $100 \%$ & $88.89 \%$ & $81.82 \%$ & $100 \%$ & $100 \%$ & $88.89 \%$ \\
\hline${ }^{1}$ Fertility test $(\%)$ & $100(90.83-100)^{a}$ & $93.54(92.98-100)^{a}$ & $100(80.95-100)^{a}$ & $100(91.29-100)^{a}$ & $96.43(88.05-100)^{a}$ & $100(94.64-100)^{\mathrm{a}}$ \\
\hline${ }^{1}$ Post-implantation loss (\%) & $0(0-0)^{a}$ & $3.33(0-7.20)^{\mathrm{a}}$ & $12.50(1.92-38.64)^{b}$ & $0(0-4.55)^{\mathrm{a}}$ & $0(0-2.08)^{\mathrm{a}}$ & $12.94(1.92-21.67)^{a b}$ \\
\hline${ }^{1}$ Sex ratio $(M: F)$ & $0.93(0.76-1.30)^{\mathrm{a}}$ & $1.00(0.87-1.53)^{\mathrm{a}}$ & $1.08(0.68-1.42)^{a}$ & $1.00(0.83-1.27)^{a}$ & $0.71(0.56-1.18)^{a}$ & $0.73(0.60-1.15)^{a}$ \\
\hline ²Body weight (GD20) & $372.20 \pm 14.86^{\mathrm{a}}$ & $392.62 \pm 12.70^{\mathrm{a}}$ & $380.44 \pm 13.72^{a}$ & $361.63 \pm 13.14^{a}$ & $395.76 \pm 9.85^{\mathrm{a}}$ & $368.80 \pm 18.46^{\mathrm{a}}$ \\
\hline${ }^{2}$ Gravid uterus & $61.24 \pm 2.13^{a}$ & $63.92 \pm 3.65^{\mathrm{a}}$ & $56.61 \pm 2.83^{a}$ & $56.09 \pm 1.29^{a}$ & $62.22 \pm 2.22^{\mathrm{a}}$ & $57.79 \pm 2.34^{\mathrm{a}}$ \\
\hline${ }^{2}$ Male fetus weight & $3.31 \pm 0.08^{a}$ & $3.12 \pm 0.14^{\mathrm{a}}$ & $3.29 \pm 0.15^{\mathrm{a}}$ & $3.29 \pm 0.07^{\mathrm{a}}$ & $3.26 \pm 0.10^{a}$ & $3.40 \pm 0.10^{\mathrm{a}}$ \\
\hline${ }^{2}$ Female fetus weight & $3.13 \pm 0.10^{a}$ & $3.05 \pm 0.11^{\mathrm{a}}$ & $3.12 \pm 0.14^{\mathrm{a}}$ & $3.11 \pm 0.09^{a}$ & $3.02 \pm 0.09^{a}$ & $3.25 \pm 0.11^{a}$ \\
\hline${ }^{2}$ Placenta weight from male fetus & $0.60 \pm 0.01^{\mathrm{a}}$ & $0.56 \pm 0.04^{\mathrm{a}}$ & $0.58 \pm 0.02^{a}$ & $0.57 \pm 0.02^{a}$ & $0.58 \pm 0.02^{a}$ & $0.59 \pm 0.03^{a}$ \\
\hline${ }^{2}$ Placenta weight from female fetus & $0.57 \pm 0.02^{a}$ & $0.56 \pm 0.04^{\mathrm{a}}$ & $0.58 \pm 0.02^{\mathrm{a}}$ & $0.56 \pm 0.02^{a}$ & $0.57 \pm 0.03^{a}$ & $0.57 \pm 0.02^{\mathrm{a}}$ \\
\hline
\end{tabular}

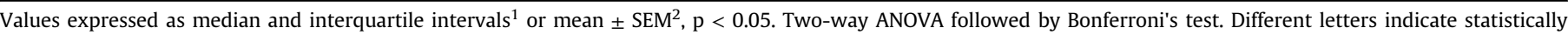
significant differences among the groups. GD = gestational day. 
Table 3

Sperm counts in the testis and epididymis from the experimental groups on PND 110.

\begin{tabular}{|c|c|c|c|c|c|c|}
\hline \multirow[t]{2}{*}{ Sperm counts } & \multicolumn{6}{|c|}{ Experimental Groups $(\mathrm{n}=10)$} \\
\hline & Control & $3 \mathrm{mg}$ & $10 \mathrm{mg}$ & AA & $3 \mathrm{mg}+\mathrm{AA}$ & $10 \mathrm{mg}+\mathrm{AA}$ \\
\hline \multicolumn{7}{|l|}{ Sperm counts in the testis } \\
\hline Mature spermatid number $\left(10^{6} /\right.$ testis $)$ & $193.60 \pm 3.36^{\mathrm{a}}$ & $153.20 \pm 4.07^{\mathrm{b}}$ & $153.50 \pm 4.11^{\mathrm{b}}$ & $197.20 \pm 4.43^{\mathrm{a}}$ & $185.70 \pm 4.70^{\mathrm{a}}$ & $184.00 \pm 5.36^{\mathrm{a}}$ \\
\hline Mature spermatid number $\left(10^{6} / \mathrm{g}\right.$ testis $)$ & $112.50 \pm 1.97^{\mathrm{a}}$ & $85.46 \pm 2.13^{b}$ & $83.80 \pm 1.71^{b}$ & $106.60 \pm 2.93^{a}$ & $109.70 \pm 3.66^{a}$ & $108.10 \pm 1.55^{\mathrm{a}}$ \\
\hline Daily sperm production $\left(10^{6} /\right.$ testis/day) & $31.73 \pm 0.55^{\mathrm{a}}$ & $25.12 \pm 0.66^{b}$ & $25.17 \pm 0.67^{b}$ & $32.31 \pm 0.72^{a}$ & $30.45 \pm 0.77^{\mathrm{a}}$ & $30.17 \pm 0.88^{a}$ \\
\hline Relative sperm production $\left(10^{6} / \mathrm{g}\right.$ testis/day) & $18.45 \pm 0.32^{a}$ & $14.11 \pm 0.41^{b}$ & $13.74 \pm 0.28^{b}$ & $17.47 \pm 0.48^{a}$ & $18.06 \pm 0.55^{\mathrm{a}}$ & $17.72 \pm 0.25^{\mathrm{a}}$ \\
\hline \multicolumn{7}{|l|}{ Sperm counts in the epididymis } \\
\hline Sperm number in the caput/corpus (x106/organ) & $140.00 \pm 4.98^{\mathrm{a}}$ & $101.60 \pm 6.53^{b}$ & $99.93 \pm 5.22^{b}$ & $126.30 \pm 5.10^{\mathrm{a}}$ & $107.60 \pm 4.42^{b}$ & $116.00 \pm 6.32^{\mathrm{ab}}$ \\
\hline Relative sperm number in the caput/corpus $\left(\times 10^{6} / \mathrm{g} /\right.$ organ $)$ & $469.30 \pm 15.11^{\mathrm{a}}$ & $372.30 \pm 13.69^{b}$ & $355.60 \pm 14.58^{b}$ & $463.40 \pm 13.03^{\mathrm{a}}$ & $458.00 \pm 20.91^{\mathrm{a}}$ & $421.80 \pm 13.68^{a}$ \\
\hline Sperm number in the cauda ( $\times 10^{6} /$ organ) & $238.40 \pm 3.80^{\mathrm{a}}$ & $203.80 \pm 7.11^{b}$ & $207.90 \pm 7.31^{b}$ & $238.60 \pm 4.94^{\mathrm{a}}$ & $232.50 \pm 8.96^{\mathrm{a}}$ & $225.80 \pm 8.89^{a}$ \\
\hline Sperm transit time in the caput/corpus (days) & $4.42 \pm 0.16^{\mathrm{a}}$ & $4.06 \pm 0.25^{\mathrm{a}}$ & $4.01 \pm 0.25^{\mathrm{a}}$ & $3.92 \pm 0.18^{\mathrm{a}}$ & $3.64 \pm 0.18^{a}$ & $3.83 \pm 0.144^{a}$ \\
\hline Sperm transit time in the cauda (days) & $7.53 \pm 0.16^{\mathrm{a}}$ & $8.13 \pm 0.22^{\mathrm{a}}$ & $8.27 \pm 0.22^{b}$ & $7.40 \pm 0.12^{\mathrm{a}}$ & $7.65 \pm 0.27^{\mathrm{a}}$ & $7.51 \pm 0.26^{\mathrm{a}}$ \\
\hline Total sperm transit time (days) & $11.94 \pm 0.26^{a}$ & $12.18 \pm 0.38^{a}$ & $12.27 \pm 0.35^{a}$ & $11.32 \pm 0.25^{a}$ & $11.41 \pm 0.39^{a}$ & $11.34 \pm 0.29^{a}$ \\
\hline
\end{tabular}

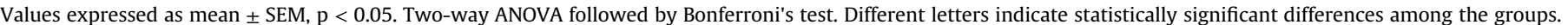

The group treated with the higher dose of the statin exhibited increased sperm transit time in the cauda, in comparison with the control group, although total sperm transit times through the epididymis were similar among the experimental groups (Table 3 ).

Rosuvastatin-treated groups showed a reduction in the rate of progressive sperm, followed by an increased frequency of nonprogressive sperm and immotile sperm, when compared to the control group ( $\mathrm{p}<0.05$ ) (Fig. 2). Ascorbic acid supplementation prevented the decreased frequency of non-progressive sperm and partially avoided the diminution of the progressive sperm percentage and the increased rate of immotile sperm (Fig. 2).

During sexual maturity, the percentage of normally shaped sperm was lower in the groups exposed to rosuvatatin at prepuberty, when compared with the control group $(\mathrm{p}<0.05)$ (Table 4$)$. Sperm head abnormalities were increased in the group treated with the lower dose of rosuvastatin whereas the group exposed to the higher dose showed an intermediate rate of sperm head abnormalities between the control group and the group treated with $3 \mathrm{mg}$ of rosuvastatin (Table 4). The main head sperm abnormality in these groups was an isolated sperm head. The sperm tail abnormalities were elevated in the statin-treated groups in a dosedependent manner while the main abnormality was a broken sperm tail ( $p<0.05$ ) (Table 4). The percentages of sperm with the cytoplasmic droplet were similar among the groups. Ascorbic-acidsupplemented groups were similar to the control group and showed no augmentation in the rate of sperm abnormalities (Table 4).

Sperm DNA damage was higher in the rosuvastatin-exposed groups in comparison to the control group (Fig. 3). Moreover, the co-exposed groups also showed increased DNA damage (Fig. 3).

\subsection{Histopathology and histomorphometry}

Rosuvastatin-exposed groups presented lower frequencies of normal seminiferous tubules, followed by increased rates of acidophilic germ cells in the germinal epithelium, in comparison with the control group ( $p<0.05)$ (Fig. 3 and Table 5). Ascorbic acid supplementation at prepuberty restored the percentage of normal seminiferous tubules and prevented the increased frequency of acidophilic germ cells in the epithelium (Fig. 4 and Table 5).

Spermatogenesis kinetics assessed by categories of seminiferous epithelium stages, the height of the seminiferous epithelium and total and luminal area of the seminiferous tubules did not show significant differences among the groups (Table 5).

Epididymal morphology demonstrated leukocyte infiltrates in the initial segment region in the statin-exposed groups (Fig. 5). Moreover, these groups exhibited an apparent hyperplasia of clear cells in the proximal cauda (Fig. 5). Ascorbic acid supplementation was able to avoid these histopathological alterations (Fig. 5).

\subsection{Body weight and organ weights}

Final body weights did not differ significantly among the experimental groups (Table 6). The groups presented similarity in not only reproductive organ weights - namely those of the testis, epididymis, vas deferens, prostate and seminal gland - but also the vital organ weights - that include those of the pituitary, thyroid, liver, adrenal, kidney and brain (Tables 6 and 7).

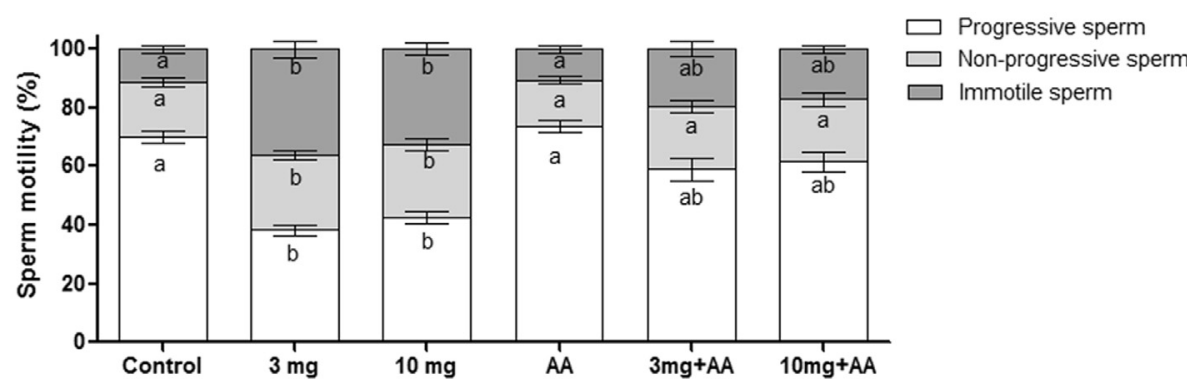

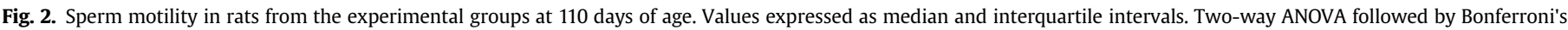
test. $\mathrm{p}<0.05$. Different letters indicate statistically significant differences among the groups. 
Table 4

Sperm morphology from the experimental groups on PND110.

\begin{tabular}{|c|c|c|c|c|c|c|}
\hline \multirow{2}{*}{$\begin{array}{l}\text { Sperm } \\
\text { morphology (\%) }\end{array}$} & \multicolumn{6}{|c|}{ Experimental Groups $(\mathrm{n}=10)$} \\
\hline & Control & $3 \mathrm{mg}$ & $10 \mathrm{mg}$ & $\mathrm{AA}$ & $3 \mathrm{mg}+\mathrm{AA}$ & $10 \mathrm{mg}+\mathrm{AA}$ \\
\hline Normal shaped sperm & $94.25(92.28-95.00)^{a}$ & $88.75(87.50-90.50)^{b}$ & $90.75(87.50-91.00)^{b}$ & $93.25(91.88-94.38)^{\mathrm{a}}$ & $91.25(88.38-93.25)^{a}$ & $92.00(91.13-95.25)^{\mathrm{a}}$ \\
\hline Abnormalities of the sperm head & $3.75(3.00-6.25)^{\mathrm{a}}$ & $7.00(5.63-11.00)^{b}$ & $6.50(5.25-10.25)^{a b}$ & $4.25(1.38-6.13)^{\mathrm{a}}$ & $6.75(4.25-9.00)^{\mathrm{a}}$ & $5.50(1.62-7.75)^{\mathrm{a}}$ \\
\hline Isolated sperm head & $3.75(3.00-5.50)^{\mathrm{a}}$ & $7.00(5.63-10.63)^{\mathrm{b}}$ & $6.50(5.25-10.25)^{a b}$ & $4.25(1.38-6.13)^{a}$ & $6.75(4.25-9.00)^{a}$ & $5.50(1.25-7.77)^{a}$ \\
\hline Abnormalities of the sperm tail & $1.75(1.38-2.63)^{\mathrm{a}}$ & $3.25(2.25-4.63)^{a b}$ & $4.00(2.50-4.37)^{b}$ & $2.75(1.00-3.63)^{a}$ & $2.00(1.50-2.63)^{\mathrm{a}}$ & $2.25(1.25-3.12)^{\mathrm{a}}$ \\
\hline Broken sperm tail & $0(0-0)^{a}$ & $0(0-1.00)^{\mathrm{a}}$ & $0(0.50-1.13)^{b}$ & $0(0.63-1.00)^{a}$ & $0(0.50-0.50)^{\mathrm{a}}$ & $0(0.50-0.50)^{\mathrm{a}}$ \\
\hline Sperm with cytoplasmic droplet & $7.25(3.88-10.50)^{a}$ & $9.75(8.38-11.88)^{a}$ & $9.75(7.50-11.63)^{a}$ & $7.25(6.13-9.50)^{\mathrm{a}}$ & $8.50(6.88-9.63)^{a}$ & $8.00(7.00-9.25)^{\mathrm{a}}$ \\
\hline
\end{tabular}

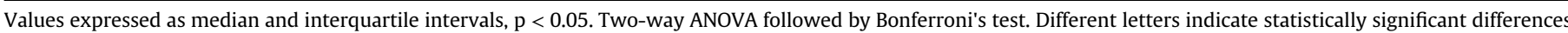
among the groups.

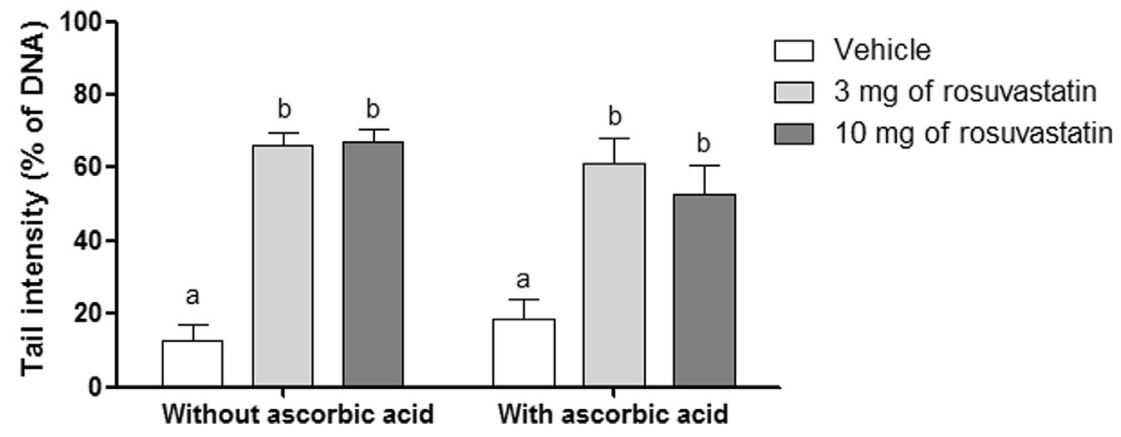

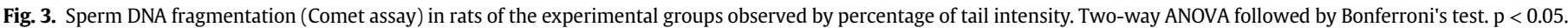
Different letters indicate statistically significant differences among the groups.

Table 5

Testicular histopathological and morphometric evaluation from the experimental groups on PND 110.

\begin{tabular}{|c|c|c|c|c|c|c|}
\hline & \multicolumn{6}{|c|}{ Experimental Groups ( $\mathrm{n}=9$ or 10 /group) } \\
\hline & Control & $3 \mathrm{mg}$ & $10 \mathrm{mg}$ & AA & $3 \mathrm{mg}+\mathrm{AA}$ & $10 \mathrm{mg}+\mathrm{AA}$ \\
\hline $\begin{array}{l}{ }^{1} \text { Normal seminiferous tubules } \\
(\%)\end{array}$ & $96.50(96.50-97.50)^{a}$ & $\begin{array}{l}94.50(89.50-96.00) \\
\text { b }\end{array}$ & $93.00(92.00-94.00)^{\mathrm{b}}$ & $97.00(96.00-97.50)^{a}$ & $95.00(95.00-97.00)^{\mathrm{a}}$ & $96.00(94.00-97.00)^{a}$ \\
\hline $\begin{array}{l}{ }^{1} \text { Seminiferous tubules with } \\
\text { acidofilic cells (\%) }\end{array}$ & $2.50(2.00-3.00)^{\mathrm{a}}$ & $4.00(3.00-5.50)^{b}$ & $6.50(3.50-6.50)^{b}$ & $2.00(1.50-3.50)^{\mathrm{a}}$ & $3.50(2.50-3.50)^{\mathrm{a}}$ & $3.50(2.50-4.00)^{a}$ \\
\hline $\begin{array}{l}{ }^{2} \text { Height of the germinal } \\
\text { epithelium }(\mu \mathrm{m})\end{array}$ & $87.20 \pm 1.75^{\mathrm{a}}$ & $87.06 \pm 1.25^{\mathrm{a}}$ & $85.28 \pm 1.02^{a}$ & $85.05 \pm 0.84^{a}$ & $86.32 \pm 0.89^{a}$ & $84.64 \pm 1.02^{a}$ \\
\hline $\begin{array}{l}{ }^{2} \text { Total area of the seminiferous } \\
\text { tubule }\left(\mu \mathrm{m}^{2}\right)\end{array}$ & $\begin{array}{l}61,355.47 \pm 1.546 .41 \\
\mathrm{a}\end{array}$ & $\begin{array}{l}63,052.42 \pm 1774.16 \\
a\end{array}$ & $\begin{array}{l}61,199.02 \pm 2.160 .30 \\
\mathrm{a}\end{array}$ & $\begin{array}{l}59,376.42 \pm 2.520 .93 \\
\mathrm{a}\end{array}$ & $\begin{array}{l}60,739.10 \pm 1.396 .99 \\
\text { a }\end{array}$ & $\begin{array}{l}60,228.03 \pm 1.595 .18 \\
\text { a }\end{array}$ \\
\hline $\begin{array}{l}{ }^{2} \text { Luminal area of the } \\
\text { seminiferous tubule }\left(\mu \mathrm{m}^{2}\right)\end{array}$ & $8690.01 \pm 467.45^{\mathrm{a}}$ & $9367.66 \pm 417.30^{a}$ & $9309.02 \pm 745.01^{a}$ & $8711.65 \pm 910.96^{a}$ & $8779.09 \pm 592.42^{a}$ & $9103.56 \pm 482.98^{a}$ \\
\hline${ }^{1}$ Stages I-VI (\%) & $31.50(30.50-31.50)^{a}$ & $\begin{array}{l}33.50(30.00-35.00) \\
\mathrm{a}\end{array}$ & $31.50(29.50-32.50)^{a}$ & $33.50(33.00-34.50)^{a}$ & $33.00(30.50-37.50)^{a}$ & $31.00(28.50-34.50)^{a}$ \\
\hline${ }^{1}$ Stages VII-VIII (\%) & $30.50(28.50-34.50)^{a}$ & $\begin{array}{l}33.50(32.50-34.00) \\
\mathrm{a}\end{array}$ & $32.50(31.00-34.00)^{a}$ & $32.00(29.00-35.00)^{a}$ & $30.00(26.00-33.00)^{a}$ & $31.50(28.00-33.50)^{a}$ \\
\hline${ }^{1}$ Stages IX-XIII (\%) & $33.00(30.50-33.50)^{a}$ & $29.50(27.00-32.50)$ & $32.00(31.00-33.00)^{\mathrm{a}}$ & $31.50(27.50-33.00)^{a}$ & $33.00(28.50-34.00)^{a}$ & $35.50(29.00-37.00)^{a}$ \\
\hline${ }^{1}$ Stage XIV (\%) & $4.50(4.00-5.50)^{\mathrm{a}}$ & $4.50(3.00-6.00)^{\mathrm{a}}$ & $3.50(3.50-4.50)^{\mathrm{a}}$ & $5.00(3.00-5.50)^{\mathrm{a}}$ & $4.50(2.50-5.00)^{\mathrm{a}}$ & $3.50(3.00-4.50)^{\mathrm{a}}$ \\
\hline
\end{tabular}

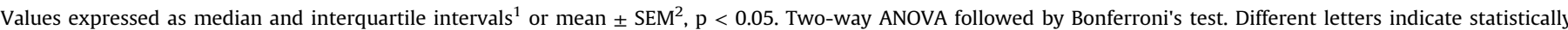
significant differences among the groups.

\section{Discussion}

The experimental design of the present study was based on the fact that obese children use lipid-lowering drugs during childhood and adolescence to decrease cholesterol and prevent cardiovascular diseases (Leite et al., 2014) and, in adulthood, stop taking medications and control their lipid profile according to health habits. Moreover, we mimicked a diet supplemented with ascorbic acid, an antioxidant vitamin, on the attempt to reduce or prevent the adverse reproductive effects caused by rosuvastatin exposure.

Although we have used normal, non-obese juvenile male Wistar rats, this study simulates human exposure to rosuvastatin during prepuberty, since atherosclerosis and fatty streaks are detectable during childhood (Ross, 2016; Wiegman et al., 2015) and, in addition, more people are benefitting from the pleiotropic effects of the statins.

Rosuvastatin is a lipid-lowering drug that reduces total cholesterol and triglycerides (Vaughan and Gotto Jr, 2004; Penning-Van Beest et al., 2007) and may reduce testosterone concentrations due to the diminution of serum cholesterol levels (Leite et al., 2014; Hsieh and Huang, 2016). A previous in vitro study evaluating rat Leydig cells treated with statins showed reduced testosterone 


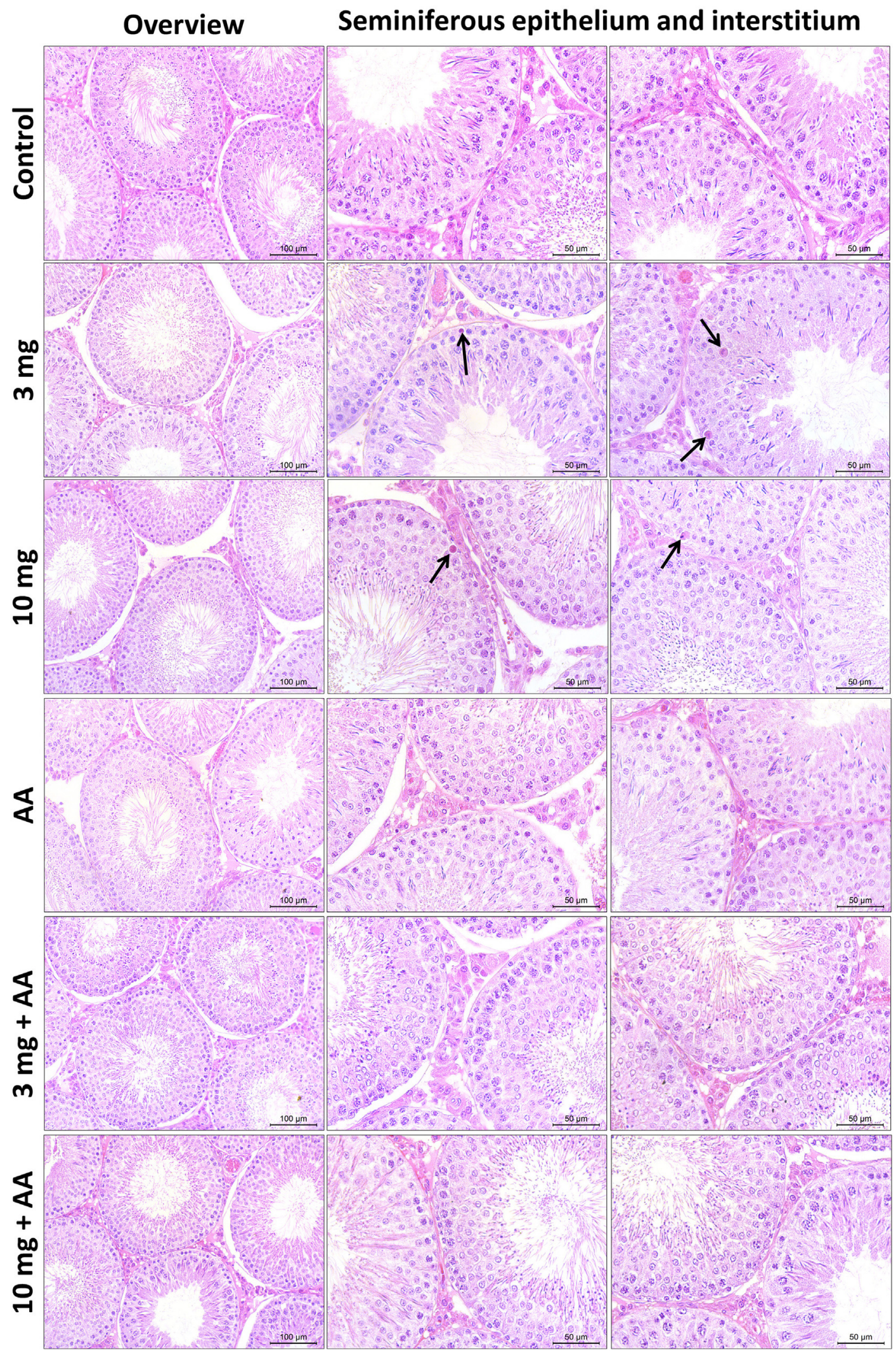

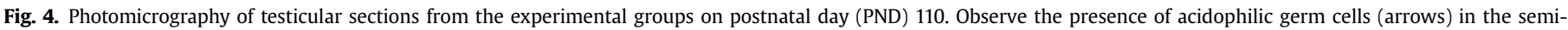
niferous epithelium of the rosuvastatin-exposed groups. Hematoxylin and Eosin (HE). Scale bar $=100 \mu \mathrm{m}$ or $50 \mu \mathrm{m}$. 


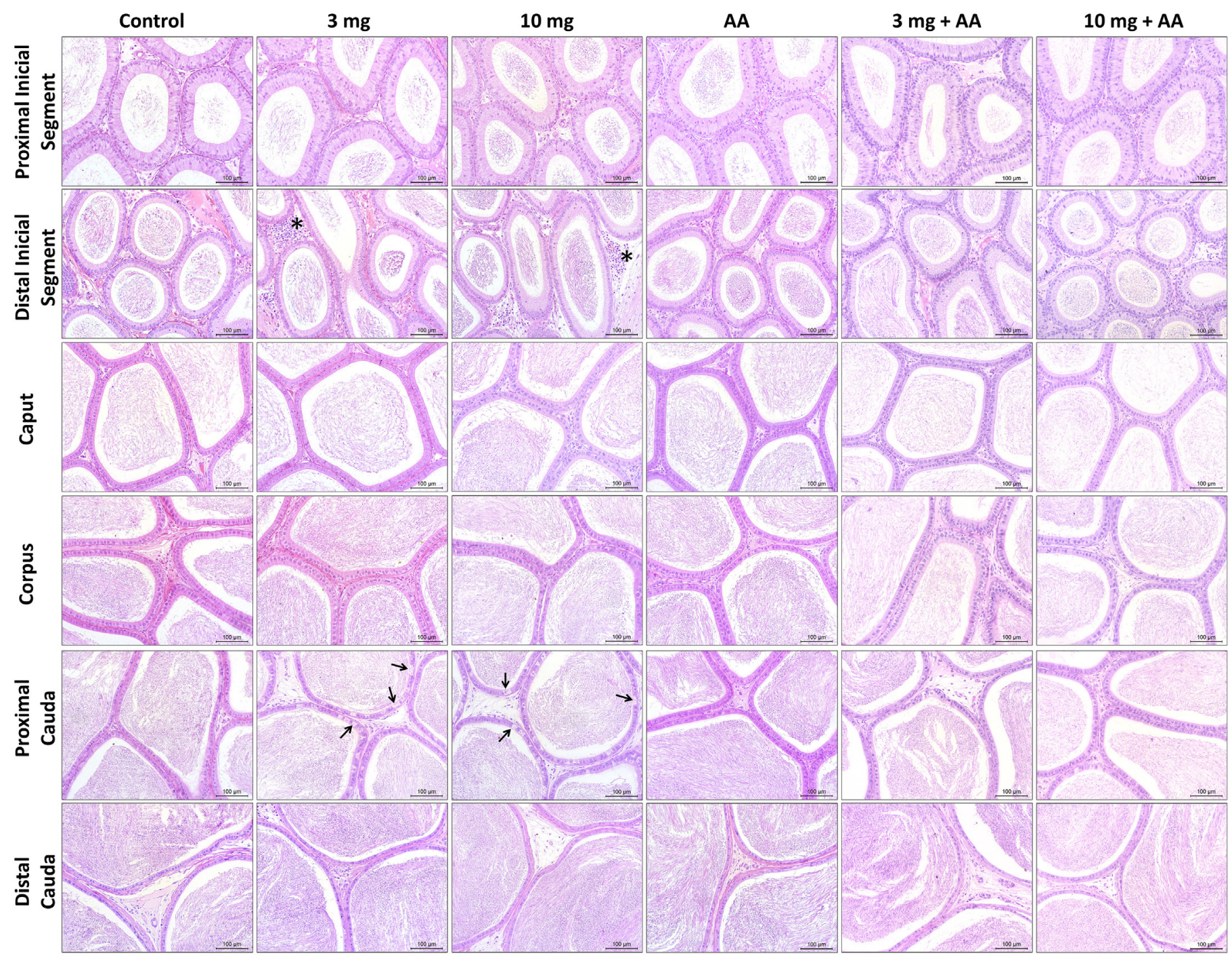

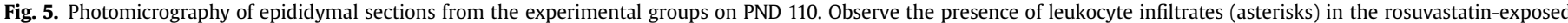

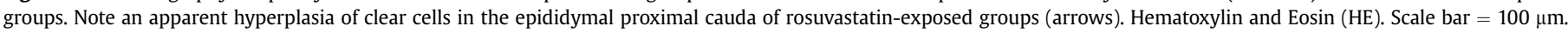

Table 6

Body weight and reproductive organ weights from the experimental groups on PND 110.

\begin{tabular}{|c|c|c|c|c|c|c|}
\hline & \multicolumn{6}{|c|}{ Experimental Groups $(\mathrm{n}=10)$} \\
\hline & Control & $3 \mathrm{mg}$ & $10 \mathrm{mg}$ & AA & $3 \mathrm{mg}+\mathrm{AA}$ & $10 \mathrm{mg}+\mathrm{AA}$ \\
\hline Final body weight (g) & $414.00 \pm 9.54$ & $426.70 \pm 10.00$ & $424.60 \pm 11.07$ & $409.80 \pm 10.87$ & $411.60 \pm 9.59$ & $381.20 \pm 13.36$ \\
\hline Testis ( $\mathrm{g}$ ) & $1.77 \pm 0.04$ & $1.81 \pm 0.04$ & $1.88 \pm 0.06$ & $1.88 \pm 0.04$ & $1.75 \pm 0.04$ & $1.75 \pm 0.04$ \\
\hline Testis (g/100 g BW) & $0.43 \pm 0.01$ & $0.43 \pm 0.01$ & $0.44 \pm 0.02$ & $0.46 \pm 0.02$ & $0.43 \pm 0.01$ & $0.47 \pm 0.02$ \\
\hline Epididymis (mg) & $622.20 \pm 13.27$ & $637.80 \pm 12.12$ & $638.90 \pm 23.79$ & $632.50 \pm 12.59$ & $614.80 \pm 10.09$ & $619.50 \pm 12.44$ \\
\hline Epididymis (mg/100 g BW) & $150.90 \pm 4.48$ & $149.90 \pm 3.42$ & $150.20 \pm 8.20$ & $155.30 \pm 5.21$ & $149.80 \pm 3.08$ & $167.80 \pm 4.94$ \\
\hline Vas deferens (mg) & $81.66 \pm 2.07$ & $83.42 \pm 3.21$ & $82.71 \pm 3.54$ & $84.73 \pm 2.51$ & $81.99 \pm 2.75$ & $79.22 \pm 2.13$ \\
\hline Vas deferens (mg/100 g BW) & $19.79 \pm 0.57$ & $19.66 \pm 0.93$ & $19.50 \pm 1.27$ & $20.78 \pm 0.73$ & $20.00 \pm 0.74$ & $21.54 \pm 0.92$ \\
\hline Prostate (mg) & $483.40 \pm 26.74$ & $551.20 \pm 40.53$ & $506.60 \pm 35.06$ & $451.20 \pm 23.56$ & $519.10 \pm 48.19$ & $449.00 \pm 35.39$ \\
\hline Prostate (mg/100 g BW) & $117.10 \pm 6.48$ & $128.90 \pm 8.72$ & $119.30 \pm 9.95$ & $111.70 \pm 7.80$ & $126.70 \pm 12.14$ & $120.60 \pm 8.28$ \\
\hline Full seminal gland (mg) & $1.52 \pm 0.08$ & $1.63 \pm 0.07$ & $1.57 \pm 0.09$ & $1.51 \pm 0.07$ & $1.58 \pm 0.07$ & $1.42 \pm 0.06$ \\
\hline Full seminal gland (mg/100 g BW) & $366.10 \pm 19.27$ & $384.60 \pm 19.14$ & $369.40 \pm 25.19$ & $368.80 \pm 17.22$ & $383.30 \pm 14.57$ & $381.60 \pm 15.99$ \\
\hline Empty seminal gland (mg) & $440.20 \pm 33.82$ & $451.60 \pm 31.13$ & $495.30 \pm 55.42$ & $435.80 \pm 26.88$ & $475.10 \pm 26.18$ & $457.50 \pm 19.72$ \\
\hline Empty seminal gland (mg/100 g BW) & $106.50 \pm 8.32$ & $107.90 \pm 8.98$ & $118.40 \pm 16.97$ & $106.60 \pm 6.41$ & $115.80 \pm 6.66$ & $124.30 \pm 7.11$ \\
\hline
\end{tabular}

Values expressed as mean \pm SEM, $\mathrm{p}>0.05$. Two-way ANOVA followed by Bonferroni's test. BW $=$ Body weight.

production when physiologically stimulated by LH (Klinefelter et al., 2014). In the present study, prepubertal exposure to rosuvastatin decreased testosterone concentrations during adulthood in a dose-dependent manner as a long-term adverse effect of the exposure to the statin. Ascorbic acid supplementation at prepuberty prevented the androgen depletion at sexual maturity. FSH and LH concentrations showed no significant differences among the groups. 
Table 7

Vital organ weights from the experimental groups on PND 110.

\begin{tabular}{|c|c|c|c|c|c|c|}
\hline & \multicolumn{6}{|c|}{ Experimental Groups $(\mathrm{n}=10)$} \\
\hline & Control & $3 \mathrm{mg}$ & $10 \mathrm{mg}$ & $\mathrm{AA}$ & $3 \mathrm{mg}+\mathrm{AA}$ & $10 \mathrm{mg}+\mathrm{AA}$ \\
\hline Pituitary (mg) & $10.04 \pm 0.42$ & $10.28 \pm 0.35$ & $9.96 \pm 0.47$ & $9.84 \pm 0.49$ & $10.04 \pm 0.53$ & $9.81 \pm 0.47$ \\
\hline Pituitary (mg/100 g BW) & $2.43 \pm 0.09$ & $2.41 \pm 0.07$ & $2.32 \pm 0.10$ & $2.37 \pm 0.14$ & $2.47 \pm 0.17$ & $2.66 \pm 0.14$ \\
\hline Thyroid (mg) & $18.18 \pm 0.98$ & $18.40 \pm 1.12$ & $18.56 \pm 1.26$ & $19.20 \pm 1.09$ & $18.54 \pm 1.04$ & $17.51 \pm 0.70$ \\
\hline Thyroid (mg/100 g BW) & $4.40 \pm 0.24$ & $4.32 \pm 0.26$ & $4.34 \pm 0.30$ & $4.68 \pm 0.23$ & $4.51 \pm 0.24$ & $4.74 \pm 0.19$ \\
\hline Liver $(g)$ & $17.16 \pm 0.58$ & $18.84 \pm 0.75$ & $16.97 \pm 0.74$ & $16.29 \pm 0.48$ & $16.38 \pm 0.47$ & $15.27 \pm 0.70$ \\
\hline Liver (g/100 g BW) & $4.14 \pm 0.10$ & $4.31 \pm 0.11$ & $3.94 \pm 0.11$ & $3.98 \pm 0.07$ & $3.98 \pm 0.07$ & $4.10 \pm 0.09$ \\
\hline Adrenal (mg) & $37.89 \pm 2.20$ & $41.51 \pm 0.74$ & $34.64 \pm 1.68$ & $37.00 \pm 2.50$ & $37.16 \pm 2.18$ & $34.74 \pm 2.58$ \\
\hline Adrenal (mg/100 g BW) & $9.16 \pm 0.50$ & $9.78 \pm 0.31$ & $8.06 \pm 0.34$ & $9.08 \pm 0.66$ & $9.07 \pm 0.59$ & $9.39 \pm 0.70$ \\
\hline Kidney $(\mathrm{g})$ & $1.51 \pm 0.03$ & $1.57 \pm 0.06$ & $1.58 \pm 0.05$ & $1.48 \pm 0.03$ & $1.48 \pm 0.04$ & $1.47 \pm 0.03$ \\
\hline Kidney (g/100 g BW) & $0.37 \pm 0.01$ & $0.37 \pm 0.01$ & $0.37 \pm 0.01$ & $0.36 \pm 0.01$ & $0.36 \pm 0.01$ & $0.40 \pm 0.01$ \\
\hline Brain $(\mathrm{g})$ & $2.07 \pm 0.02$ & $2.05 \pm 0.03$ & $2.08 \pm 0.03$ & $2.06 \pm 0.05$ & $2.05 \pm 0.02$ & $1.97 \pm 0.03$ \\
\hline Brain (g/100 g BW) & $0.50 \pm 0.01$ & $0.48 \pm 0.01$ & $0.49 \pm 0.01$ & $0.51 \pm 0.01$ & $0.50 \pm 0.01$ & $0.54 \pm 0.02$ \\
\hline
\end{tabular}

Values expressed as mean \pm SEM, $\mathrm{p}>0.05$. Two-way ANOVA followed by Bonferroni's test. BW $=$ Body weight.

Statins decrease androgen synthesis by reducing expression and isoprenylation of CYP17A1, as previously demonstrated in an in vitro study of theca-interstitial cells (Ortega et al., 2014, 2012). Ascorbic acid is not only responsible for up to $65 \%$ of antioxidant action on semen (Fernandes et al., 2011a; Makker et al., 2009), but also for stimulating the steroidogenic enzymes $3 \beta-H S D, 17 \beta-H S D$ and StAR protein in testes and increasing LH expression in Leydig cells, leading to augmented androgen biosynthesis (Harikrishnan et al., 2013; Radhakrishnakartha et al., 2014).

A recent study has shown that ascorbic acid was able to improve both testosterone concentrations and antioxidant status in pubescent rats exposed to rosuvastatin during prepuberty (Leite et al., 2017), since ascorbic acid is capable of stimulating Leydig-cell steroidogenic enzymes and neutralizing such free radicals as hydrogen peroxide, superoxide and hydroxyl (Harikrishnan et al., 2013; Leite et al., 2017; Makker et al., 2009; Radhakrishnakartha et al., 2014).

Reduced testosterone levels hamper germ-cell survival since Sertoli cells need androgens to bind to their androgen receptors to produce proteins associated with the maintenance and survival of the germ cells (De Gendt et al., 2004; Stanton et al., 2012). Androgen depletion may increase oxidative stress and provoke an augmentation of DNA damage and fragmentation, leading to germ cell death (Stanton et al., 2012). Indeed, an increased amount of sperm DNA damage after exposure to either rosuvastatin dose (3 or $10 \mathrm{mg}$ ) was observed. Moreover, juvenile exposure to either rosuvastatin dose increased the percentage of seminiferous tubules with acidophilic germ cells, an indication of germ cell death, probably due to androgen depletion observed during adulthood. Ascorbic acid supplementation was able to prevent the increased rate of germ cell death. However, the height of germinal epithelium, spermatogenesis kinetics and the luminal and total area of the seminiferous tubules were similar among the groups.

The epididymal morphology of rosuvastatin-exposed animals presented augmented inflammation in the initial segment of the organ, which may be related to androgen depletion that increases TNF- $\alpha$ and other inflammatory mediators and leads to inflammation (Chen et al., 2016). Furthermore, epididymis histology of rosuvastatin-treated groups exhibited an apparent hyperplasia at the proximal cauda that seems to be associated with delayed differentiation of epididymal epithelium (Leite et al., 2014).

Diminished sperm counts have been reported as a toxic effect on male reproduction and are correlated with lower fertility in males (Perreault and Cancel, 2001). Abnormalities of sperm head or tail have been utilized as an indicator of damage that is occurring in testes during spermatogenesis due to a toxic action of chemical compounds (Filler, 1993). Moreover, reduced sperm motility is associated with a toxic effect on the epididymis, suggesting adverse effects on sperm maturation (Perreault, 1998; Perreault and Cancel, 2001). In this work, rosuvastatin-treated groups showed reduced sperm motility, diminished sperm counts and increased abnormalities of sperm, thus showing lower sperm quality at sexual maturity. On the other hand, ascorbic acid supplementation might partially prevent these effects, thus improving sperm quality in adulthood.

One previous study showed increased DNA damage in nigrostriatal neurons of mice exposed to different statins, namely pravastatin, simvastatin and atorvastatin (Coetsee et al., 2008). Exposure to toxicants or defective replication during meiosis may produce chromosomal abnormalities such as structural changes or an irregular number of chromosomes, which can result in spontaneous abortions during gestation (Hales et al., 2005). In addition, modifications in paternal DNA sequences or epigenetic changes may interfere with early embryo development (Hales et al., 2005); therefore, the paternal genome integrity is closely related to the embryonic fate (Hales et al., 2005; Marchetti et al., 2003). Rosuvastatin-treated groups exhibited increased DNA fragmentation, but only the group exposed to the highest rosuvastatin dose showed an augmented rate of post-implantation loss after natural mating, indicating that lower integrity of sperm DNA may impair embryo development. Ascorbic acid supplementation partially diminished the rate of post-implantation loss in the co-exposed group. On the other hand, sexual behavior and other parameters employed to assess reproductive performance did not show significant differences among the experimental groups.

The assessment of final body weight supplies relevant information about the health of the rats (Clegg et al., 2001). In association with body weight, reproductive organ weights provide information about the reproductive status (Clegg et al., 2001), whereas vital organ weights indicate the health condition of the respective organs. In this study, final body weight and the reproductive and vital organ weights were found to be similar among the experimental groups.

In summary, prepubertal exposure to rosuvastatin increased the frequency of germ cell death in the testes, provoked epididymal inflammation, hyperplasia of clear cells in the epididymis cauda and reduced sperm quality, at both doses. Furthermore, exposure to the higher dose of the statin increased the rate of post-implantation loss. Ascorbic acid supplementation during prepuberty partially avoided the reproductive impairment at sexual maturity. Reproductive damage provoked by juvenile exposure to rosuvastatin and the main protective effects of ascorbic acid during prepuberty (Leite et al., 2017) appeared to persist into sexual maturity. 


\section{Conclusions}

Prepubertal exposure to rosuvastatin diminishes testosterone concentration and sperm quality, increases sperm DNA fragmentation and impairs testicular and epididymal structure during adulthood, in rats. On the other hand, ascorbic acid supplementation partially ameliorates the rosuvastatin-induced damage. We conclude that juvenile exposure to rosuvastatin is a probable risk for male reproduction, whereas ascorbic acid supplementation during the same period may be a means of preventing, at least partially, the long-term reproductive damage generated by rosuvastatin therapy.

\section{Declaration of interest}

The authors declare that there are no conflicts of interest.

\section{Acknowledgments}

The authors are grateful to the São Paulo Research Foundation (FAPESP) (Grants \#013/22495-1 and \#014/13659-3), National Council for Scientific and Technological Development (CNPq) (Grant 308842/2013-8) and Coordination for the Improvement of Higher Education Personnel (CAPES) for their financial support, to José Eduardo Bozano, from the Department of Morphology, Institute of Biosciences, UNESP, Botucatu/SP - Brazil, for his excellent technical assistance and to Dr. Daisy Maria Fávero Salvadori, from the Department of Pathology, Medical School, UNESP, Botucatu/SP - Brazil, for her relevant contributions with the Sperm Comet Assay.

\section{Transparency document}

Transparency document related to this article can be found online at https://doi.org/10.1016/j.fct.2017.09.003.

\section{References}

Adam, O., Laufs, U., 2008. Antioxidative effects of statins. Arch. Toxicol. http:// dx.doi.org/10.1007/s00204-008-0344-4.

Agarwal, A., Prabhakaran, S.A., Said, T.M., 2005. Prevention of oxidative stress injury to sperm. J. Androl. 26, 654-660. http://dx.doi.org/10.2164/jandrol.05016.

Ahlenius, S., Larsson, K., 1984. Apomorphine and haloperidol-induced effects on male-rat sexual-behavior - No evidence for actions due to stimulation of central dopamine autoreceptors. Pharmacol. Biochem. Behav. 21, 463-466.

Chen, C.-W., Jian, C.-Y., Lin, P.-H., Chen, C.-C., Lieu, F.-K., Soong, C., Hsieh, C.-C., Wan, C.-Y., Idova, G., Hu, S., Wang, S.-W., Wang, P.S., 2016. Role of testosterone in regulating induction of TNF- $\alpha$ in rat spleen via ERK signaling pathway. Steroids 111, 148-154. http://dx.doi.org/10.1016/j.steroids.2016.03.007.

Clegg, E.D., Perreault, S.D., Klinefelter, G.R., 2001. Assessment of male reproductive toxicology. In: Hayes, A. (Ed.), Principles and Methods of Toxicology. Taylor \& Francis, Philadelphia, pp. 1263-1299.

Coetsee, T.N., Pretorius, P.J., Terre'Blanche, G., Bergh, J.J., 2008. Investigating the potential neuroprotective effects of statins on DNA damage in mouse striatum. Food Chem. Toxicol. 46, 3186-3192. http://dx.doi.org/10.1016/j.fct.2008.07.006.

Corsetti, G., Stacchiotti, A., Tedesco, L., D'Antona, G., Pasini, E., Dioguardi, F.S. Nisoli, E., Rezzani, R., 2011. Essential amino acid supplementation decreases liver damage induced by chronic ethanol consumption in rats. Int. J. Immunopathol. Pharmacol. 24, 611-619.

De Gendt, K., Swinnen, J.V., Saunders, P.T.K., Schoonjans, L., Dewerchin, M., Devos, A., Tan, K., Atanassova, N., Claessens, F., Lécureuil, C., Heyns, W., Carmeliet, P., Guillou, F., Sharpe, R.M., Verhoeven, G., 2004. A Sertoli cellselective knockout of the androgen receptor causes spermatogenic arrest in meiosis. Proc. Natl. Acad. Sci. U. S. A. 101, 1327-1332. http://dx.doi.org/10.1073/ pnas.0308114100.

Endres, M., 2006. Statins: potential new indications in inflammatory conditions. Atheroscler. Suppl. http://dx.doi.org/10.1016/j.atherosclerosissup.2006.01.005.

Eskenazi, B., Kidd, S.A., Marks, A.R., Sloter, E., Block, G., Wyrobek, A.J., 2005. Antioxidant intake is associated with semen quality in healthy men. Hum. Reprod. 20, 1006-1012. http://dx.doi.org/10.1093/humrep/deh725.

Fernandes, G.S.A., Fernandez, C.D.B., Campos, K.E., Damasceno, D.C., AnselmoFranci, J.A., Kempinas, W.D.G., 2011a. Vitamin C partially attenuates male reproductive deficits in hyperglycemic rats. Reprod. Biol. Endocrinol. 100, 1-9. http://dx.doi.org/10.1186/1477-7827-9-100.

Fernandes, G.S.A., Gerardin, D.C.C., Assumpção, T.A., Campos, K.E., Damasceno, D.C. Pereira, O.C.M., Kempinas, W.D.G., 2011b. Can vitamins C and E restore the androgen level and hypersensitivity of the vas deferens in hyperglycemic rats? Pharmacol. Rep. 63, 983-991.

Filler, R., 1993. Methods for evaluation of rats epididymal sperm morphology. In: Chapin, R.E., Heindel, J.H. (Eds.), Male Reproductive Toxicology. Press, Academic, San Diego, pp. 334-343.

Hales, B.F., Aguilar-Mahecha, A., Robaire, B., 2005. The stress response in gametes and embryos after paternal chemical exposures. Toxicol. Appl. Pharmacol. 207, 514-520. http://dx.doi.org/10.1016/j.taap.2004.12.021.

Harikrishnan, R., Abhilash, P.A., Syam Das, S., Prathibha, P., Rejitha, S., John, F. Kavitha, S., Indira, M., 2013. Protective effect of ascorbic acid against ethanolinduced reproductive toxicity in male Guinea pigs. Br. J. Nutr. 110, 689-698. http://dx.doi.org/10.1017/S0007114512005739.

Holdgate, G.A., Ward, W.H.J., McTaggart, F., 2003. Molecular mechanism for inhibition of 3-hydroxy-3-methylglutaryl CoA (HMG-CoA) reductase by rosuvastatin. Biochem. Soc. Trans. 31, 528-531. http://dx.doi.org/10.1042/BST0310528.

Hsieh, C.J., Huang, B., 2016. Rosuvastatin decreases testosterone levels but not sexual function in men with type 2 diabetes. Diabetes Res. Clin. Pract. 120 81-88. http://dx.doi.org/10.1016/j.diabres.2016.07.026.

Istvan, E.S., Deisenhofer, J., 2001. Structural mechanism for statin inhibition of HMG-CoA reductase. Sci. (80-. ) 292, 1160-1164. http://dx.doi.org/10.1126/ science.1059344.

Jiménez, E.G., Ferre, J.A., 2011. Estatinas: características y efectos sobre el control lipídico en el niño y adolescente obeso. Rev. Clínica Med. Fam. 4, 69-75.

Klinefelter, G.R., Laskey, J.W., Amann, R.P., 2014. Statin drugs markedly inhibit testosterone production by rat Leydig cells in vitro: implications for men. Reprod. Toxicol. 45, 52-58. http://dx.doi.org/10.1016/j.reprotox.2013.12.010.

Klop, B., Elte, J.W.F., Cabezas, M.C., 2013. Dyslipidemia in obesity: mechanisms and potential targets. Nutrients. http://dx.doi.org/10.3390/nu5041218.

Leblond, C.P., Clermont, Y., 1952. Spermiogenesis of rat, mouse,hamster and Guinea pig as revealed by the "periodic acid-fuchsin sulfurous acid" technique. Am. J. Anat. 90, 167-215.

Leite, G.A.A., Figueiredo, T.M., Sanabria, M., Dias, A.F.M.G., Silva, P.V., Martins Junior, A. da C., Barbosa Junior, F., Kempinas, W.D.G., 2017. Ascorbic acid supplementation partially prevents the delayed reproductive development in juvenile male rats exposed to rosuvastatin since prepuberty. Reprod. Toxicol. http://dx.doi.org/10.1016/j.reprotox.2017.07.006.

Leite, G.A.A., Rosa, J. de L., Sanabria, M., Cavariani, M.M., Franci, J.A.A., Pinheiro, P.F.F. Kempinas, W.D.G., 2014. Delayed reproductive development in pubertal male rats exposed to the hypolipemiant agent rosuvastatin since prepuberty. Reprod. Toxicol. 44, 93-103. http://dx.doi.org/10.1016/j.reprotox.2014.01.004.

Ludman, A., Venugopal, V., Yellon, D.M., Hausenloy, D.J., 2009. Statins and cardioprotection - more than just lipid lowering? Pharmacol. Ther. 122, 30-43. http://dx.doi.org/10.1016/j.pharmthera.2009.01.002.

Makker, K., Agarwal, A., Sharma, R., 2009. Oxidative stress \& male infertility. Indian J. Med. Res. 357-367.

Mantovani, A., Fucic, A., 2014. Puberty dysregulation and increased risk of disease in adult life: possible modes of action. Reprod. Toxicol. http://dx.doi.org/10.1016 j.reprotox.2013.06.002.

Marchetti, F., Bishop, J.B., Consentino, L., Moore II, L., Wyrobek, A.J., 2003. Paternally transmitted chromosomal aberrations in mouse zygotes determine their embryonic fate. Biol. Reprod. 70, 616-624. http://dx.doi.org/10.1095/ biolreprod.103.023044.

McGill, H.C., McMahan, C.A., Herderick, E.E., Zieske, A.W., Malcom, G.T., Tracy, R.E., Strong, J.P., 2002. Obesity accelerates the progression of coronary atherosclerosis in young men. Circulation 105, 2712-2718. http://dx.doi.org/10.1161/ 01.CIR.0000018121.67607.CE.

McTaggart, F., 2003. Comparative pharmacology of rosuvastatin. Atheroscler. Suppl. 4, 9-14. http://dx.doi.org/10.1016/S1567-5688(03)00004-7.

Mukhopadhyay, P.K., Dey, A., Mukherjee, S., Pradhan, N.K., 2013. The effect of coadministration of alpha-tocopherol and ascorbic acid on arsenic trioxideinduced testicular toxicity in adult rats. J. Basic Clin. Physiol. Pharmacol. 24, 245-253. http://dx.doi.org/10.1515/jbcpp-2012-0039.

Ortega, I., Cress, A.B., Wong, D.H., Villanueva, J.a., Sokalska, A., Moeller, B.C. Stanley, S.D., Duleba, A.J., 2012. Simvastatin reduces steroidogenesis by inhibiting Cyp17a1 gene expression in rat ovarian theca-interstitial cells. Biol. Reprod. 86, 1-9. http://dx.doi.org/10.1095/biolreprod.111.094714.

Ortega, I., Villanueva, J.A., Wong, D.H., Cress, A.B., Sokalska, A., Stanley, S.D., Duleba, A.J., 2014. Resveratrol potentiates effects of simvastatin on inhibition of rat ovarian theca-interstitial cells steroidogenesis. J. Ovarian Res. 7, 21. http:// dx.doi.org/10.1186/1757-2215-7-21.

Pandir, D., Kara, O., Kara, M., 2014. Protective effect of bilberry (Vaccinium myrtillus L.) on cisplatin induced ovarian damage in rat. Cytotechnology 66, 677-685. http://dx.doi.org/10.1007/s10616-013-9621-z.

Penning-Van Beest, F.J.A., Termorshuizen, F., Goettsch, W.G., Klungel, O.H., Kastelein, J.J.P., Herings, R.M.C., 2007. Adherence to evidence-based statin guidelines reduces the risk of hospitalizations for acute myocardial infarction by $40 \%$ : a cohort study. Eur. Heart J. 28, 154-159. http://dx.doi.org/10.1093/ eurheartj/ehl391.

Perobelli, J.E., Alves, T.R., de Toledo, F.C., Fernandez, C.D.B., Anselmo-Franci, J.A. Klinefelter, G.R., Kempinas, W.D.G., 2012. Impairment on sperm quality and fertility of adult rats after antiandrogen exposure during prepuberty. Reprod. Toxicol. 33, 308-315. http://dx.doi.org/10.1016/j.reprotox.2011.12.011. 
Perobelli, J.E., Patrão, M.T.C.C., Fernandez, C.D.B., Sanabria, M., Klinefelter, G.R., Avellar, M.C.W., Kempinas, W.D.G., 2013. Androgen deprivation from prepuberty to peripuberty interferes in proteins expression in pubertal and adult rat epididymis. Reprod. Toxicol. 38, 65-71. http://dx.doi.org/10.1016/ j.reprotox.2013.03.004

Perreault, S.D., 1998. Gamete toxicology: the impact of new technologies. In: Dekker, M. (Ed.), Reproductive and Developmental Toxicology. KS. Korach, New York, pp. 635-654.

Perreault, S.D., Cancel, A.M., 2001. Significance of incorporating measures of sperm production and function into rat toxicology studies. Reproduction 121, 207-216. http://dx.doi.org/10.1530/reprod/121.2.207.

Pons-Rejraji, H., Brugnon, F., Sion, B., Maqdasy, S., Gouby, G., Pereira, B., Marceau, G. Gremeau, A.-S., Drevet, J., Grizard, G., Janny, L., Tauveron, I., 2014. Evaluation of atorvastatin efficacy and toxicity on spermatozoa, accessory glands and gonadal hormones of healthy men: a pilot prospective clinical trial. Reprod. Biol. Endocrinol. 12, 65. http://dx.doi.org/10.1186/1477-7827-12-65.

Radhakrishnakartha, H., Appu, A.P., Indira, M., 2014. Ascorbic acid supplementation enhances recovery from ethanol induced inhibition of Leydig cell steroidogenesis than abstention in male Guinea pigs. Eur. J. Pharmacol. 723, 73-79. http://dx.doi.org/10.1016/j.ejphar.2013.12.010.

Reagan-Shaw, S., Nihal, M., Ahmad, N., 2008. Dose translation from animal to human studies revisited. FASEB J. 22, 659-661. http://dx.doi.org/10.1096/fj.079574LSF.

Robb, G.W., Amann, R.P., Killian, G.J., 1978. Daily sperm production and epididymal sperm reserves of pubertal and adult rats. J. Reprod. Fertil. 54, 103-107. http:// dx.doi.org/10.1530/jrf.0.0540103.

Ross, J.L., 2016. Statins in the management of pediatric dyslipidemia. J. Pediatr. Nurs. 31, 723-735. http://dx.doi.org/10.1016/j.pedn.2016.07.004.

Seed, J., Chapin, R.E., Clegg, E.D., Dostal, L.A., Foote, R.H., Hurtt, M.E., Klinefelter, G.R., Makris, S.L., Perreault, S.D., Schrader, S., Seyler, D., Sprando, R., Treinen, K.A. Veeramachaneni, D.N.R., Wise, L.D., 1996. Methods for assessing sperm motility, morphology, and counts in the rat, rabbit, and dog: a consensus report. Reprod. Toxicol. 10, 237-244. http://dx.doi.org/10.1016/0890-6238(96)00028-7.

Seth, A., Sharma, R., 2013. Childhood obesity. Indian J. Pediatr. 80, 309-317. http:// dx.doi.org/10.1007/s12098-012-0931-5.

Shrilatha, B., Muralidhara, 2007. Early oxidative stress in testis and epididymal sperm in streptozotocin-induced diabetic mice: its progression and genotoxic consequences. Reprod. Toxicol. 23, 578-587. http://dx.doi.org/10.1016/ reprotox.2007.02 001

Sönmez, M., Turk, G., Yuce, A., 2005. The effect of ascorbic acid supplementation on sperm quality, lipid peroxidation and testosterone levels of male Wistar rats. Theriogenology 63, 2063-2072. http://dx.doi.org/10.1016/ j.theriogenology.2004.10.003.

Sooriyaarachchi, M., Narendran, A., Gailer, J., 2012. The effect of sodium thiosulfate on the metabolism of cis-platin in human plasma in vitro. Metallomics 4, 960-967. http://dx.doi.org/10.1039/c2mt20076g.

Stanton, P.G., Sluka, P., Foo, C.F.H., Stephens, A.N., Smith, A.I., Mclachlan, R.I., Donnell, L.O., 2012. Proteomic changes in rat spermatogenesis in response to in vivo androgen manipulation: impact on meiotic cells. PLoS One 7, 1-19. http://dx.doi.org/10.1371/journal.pone.0041718.

Stoker, T.E., Laws, S.C., Guidici, D.L., Cooper, R.L., 2000. The effect of atrazine on puberty in male wistar rats: an evaluation in the protocol for the assessment of pubertal development and thyroid function. Toxicol. Sci. 58, 50-59. http:// dx.doi.org/10.1093/toxsci/58.1.50.

Tandon, V., Bano, G., Khajuria, V., Parihar, A., Gupta, S., 2005. Pleiotropic effects of statins. Indian J. Pharmacol. 37, 77-85. http://dx.doi.org/10.5772/23502.

Tice, R.R., Agurell, E., Anderson, D., Burlinson, B., Hartmann, A., Kobayashi, H. Miyamae, Y., Rojas, E., Ryu, J.-C., Sasaki, Y.F., 2000. Single cell gel/comet assay: guidelines for in vitro and in vivo genetic toxicology testing. Environ. Mol. Mutagen 35, 206-221.

Vaughan, C.J., Gotto Jr., A.M., 2004. Update on statins: 2003. Circulation 110 886-892. http://dx.doi.org/10.1161/01.CIR.0000139312.10076.BA.

Wiegman, A., Gidding, S.S., Watts, G.F., Chapman, M.J., Ginsberg, H.N., Cuchel, M., Ose, L., Averna, M., Boileau, C., Borén, J., Bruckert, E., Catapano, A.L., Defesche, J.C., Descamps, O.S., Hegele, R.A., Hovingh, G.K., Humphries, S.E., Kovanen, P.T., Kuivenhoven, J.A., Masana, L., Nordestgaard, B.G., Pajukanta, P., Parhofer, K.G., Raal, F.J., Ray, K.K., Santos, R.D., Stalenhoef, A.F.H., SteinhagenThiessen, E., Stroes, E.S., Taskinen, M.R., Tybjealigrg-Hansen, A., Wiklund, O. Catapano, A.L., Defesche, J.C., Descamps, O.S., Gidding, S.S., Ginsberg, H.N., Hegele, R.A., Humphries, S.E., Kovanen, P.T., Nordestgaard, B.G., Parhofer, K.G., Raal, F.J., Ray, K.K., Santos, R.D., Stalenhoef, A.F.H., Steinhagen-Thiessen, E., Stroes, E.S., Watts, G.F., 2015. Familial hypercholesterolaemia in children and adolescents: gaining decades of life by optimizing detection and treatment. Eur. Heart J. 36, 2425-2437. http://dx.doi.org/10.1093/eurheartj/ehv157. 